\title{
EMPLOYEE RELATIONS MODEL FOR THE BOTSWANA PUBLIC SERVICE SECTOR
}

\author{
Theophilus TSHUKUDU*
}

\begin{abstract}
This paper seeks to evaluate the employee relations model for the Botswana Public Service Sector by looking at the current practices compared to what it ought or suitable to be as per the unavoidable ever-changing working environment. The employee relations practices in Botswana public sector and policies formulated and implemented since the attainment of independence in September 1966 rarely makes reference to the manner in which organizational culture really impact in the attainment of goals and objectives. The aim is to identify arrears of concern that need attention as far as the employment relation dynamics are concerned. It will critically look in to the practices that are suitable enough to develop recommendable employee relations that is effective in order to sustain good working relationships in the public sector. The public sector is experiencing more of threats and weaknesses which pose major problems to the country's ability to compete globally in terms of providing public service. It is therefore important to investigate and come up with strategies that will improve and yield a long lasting working relationship between the employee and the employer. At the end of the study it should be possible to realise that even though the public sector's number one priority is not making profits, effective employment relations are key in any organisation to yield an effectiveness corporate culture that will benefit all stakeholders.
\end{abstract}

Keywords: Botswana public service; employee relations; models.

DOI 10.53373/ REDS.2022.55.2.0069

\section{INTRODUCTION}

Employee relations is the union between the employer and the employee, which its focus is on the sole purpose of achieving the organisational mandate. In this relationship both concerned parties have obligations and expectations towards each other. (Armstrong 2009:878) states that employee relations are concerned with managing and ensuring a good employment relationship, which involves handling the pay work bargain, dealing with employment practices, looking at the terms and working conditions of employee,issues arising from employment. They consist of the approaches and methods adopted by employers to deal with employees either collectively through their trade unions or individually. It combines employee welfare, their health and safety, employee involvement and participation and industrial relation aspect, and their services. It does not only look at industrial relations as perceived, but it involves the aspect of psychological contract between the employee and employer.

* Faculty of Business, Department of Management, University of Botswana. 
Employee relation is conceived as a replacement for the term industrial relation but it's precise meaning in today's workplaces needs clarification but (Armstrong 2009: 878) emphasized that the term employee relations include the industrial relations, which are about relationships between managements and trade unions involving employee discipline, industrial disputes, labor welfare and collective bargaining.(Safework 2020) explains industrial relations as the relationship between employees and management which stem indirectly or directly from union employer relationship. The employee relation is based on the pay-work bargain, that's the agreement made between employers and employees whereby the former undertakes to pay for the work done by latter.

The efforts to employ good relations between the Botswana government and public servants were documented in the NDP 8 . The government sought to establish a consultative machinery to be used for collective bargaining purposes as well as management of labour disputes. The establishment of the consultative machinery would include the resuscitation of the consultative structures at the local and regional level i.e. at the Regional and Local Works Committees (Republic of Botswana 2002). Relations between government and trade unions are limited in terms participation of both parties in tripartite structure such as the Labour Advisory Board, the Minimum Wages Advisory Board and other such structures set up by government where the labour movement is deemed to be a stakeholder (Friedrich Ebert Foundation 2008:31). The participation of trade unions is, however, not very significant in terms of their ability to influence government decisions and policies particularly since their role is advisory and consequently, the government is not bound to accept any of its views or propositions in those forums (Elischer 2008:31). However, an effective employee relation centers around developing a spirit of working together towards achieving a common purpose which encompasses friendly atmosphere, equitable and fair treatment. Therefore, the union between the employer and the employee should start with both of them building a cordial relationship that yield a friendly atmosphere and a sound employment relation.

\section{BACKGROUND OF STUDY}

The public service in Botswana is the principal actor in macro socio-economic policy making infrastructure and an architect of an enabling environment for national development. The public service in Botswana consists of civil servants, all disciplined forces, local authority staff, judiciary, ombudsman, teaching service management and parliamentary staff. The Botswana public service vision reads 'We, the Botswana Public Service, will provide a world class service that is efficient, effective, caring and responsive to local and global challenges', and the mission statement reads:

The Botswana Public Service exists to provide efficient and cost effective service for its customers and stakeholders through the formulation and management of government policies. The Public Service will implement sustainable performance 
improvement programs; provide essential services that are not otherwise accessible to the public; and create a sustainable and conducive environment for quality service delivery. The delivery of services will be provided in a caring, transparent, politically neutral, reliable, responsive, proactive and accountable manner and in partnership with all stakeholders. This Public Service will have a supportive culture that is customer and stakeholder focused; that rewards performance and empowers all. It will be supported and driven by up-to-date Technology. (Directorate of Public Service Management (DPSM), 1999)

Though we have the ER regulations in place it was not until 1969 that the first pieces of legislation ever passed by the new government after independence improving the Trade Unions and Trade Dispute Proclamation and Employment Law No. 15 of 1963, which was replaced by the Trade Unions Act No.24 of 1969, the Trade Dispute Act No. 28 of 1969 and the Regulation of Wages and Conditions of Employment Act of 1969. These Acts came into force in August 1969. (Cooper 1985). Trade Unions Act No.24 of 1969 came into force on the 8th. August 1969 provided for the amendment and the consolidation of the law relating to the registration of Trade Unions and other purposes; the Trade Dispute Act No. 28 of 1969 came into force in 1st. August 1969 provided for the establishment of the Industrial Arbitration Tribunal and Board of inquiry as well as to make provisions for the settlement of Trade Disputes and to control and regulate Strike Action and Lockouts. The Regulation of Wages and Conditions of Employment Act of 1968 which also came into force in 1st. August 1969 provided for the establishment of Wages Councils and regulation of remuneration as well as conditions of employment. These Acts were overtaken by events and as a result amendments were introduced in 1982/83 and later in 2004.These included an overhauled Employment Act, a comprehensive Trade Dispute Act and Trade Union and Employers Organizations' Act which for the first time made provision for employer organization.

Mwatcha (2015:4) sensitized that in order to achieve its mission, vision and to respond to the challenges of globalization the Botswana Government introduced a number of reform initiatives in the public service. These include performance management system (PMS), work improvement teams (WITS), computerized personnel management system (CPMS), organization and methods (O\&M), privatization, performance-based reward system (PBRS), parallel progression, scarce skills, job evaluation, localization and decentralization. The primary purpose of these new initiatives was to create an enabling environment aimed at strengthening public-sector-wide institutional capacity. Further, the reform initiatives are meant to improve individual and organizational performance in a systematic way, to enable government to improve performance and enhance its capacity to provide efficient service delivery to Batswana. (Mwatcha 2015:4) added that in addition, these new initiatives are essential in driving the public service towards the successful implementation of projects, policies and programs as outlined in National Development Plans (NDPs) and the Botswana national Vision 2016. Vision 2016 is Botswana's strategy to propel its socio-economic and political 
development into a competitive, winning and prosperous nation. In addition to the above reform initiatives, the government has realized that the effectiveness of the public service is, among other things (other things include financial resources, adequate manpower and appropriate technology), dependent on training public servants to equip them with the necessary skills, knowledge and understanding towards the realization of the public service mission, vision and goals. Hence public service training is yet another reform initiative that is critical in enhancing performance in public service delivery.

The Government of Botswana has since developed a Training Management Handbook to provide clear guidelines for planning, implementation, monitoring and evaluation of the public sector training (Directorate of Public Service Management, 1999). The Government of Botswana public sector reform initiative is timely and innovative. It depends upon a thorough culture of change in the public service and therefore, it is incumbent on all public service employees to embrace the vision and play their part in effecting such change.

\section{PROBLem STATEMENT}

The Botswana Public Service Sector has since been downgraded by various stakeholders as one the poorest compared to the rest of the world. However, one may attest to the fact that this is due to poor approaches employee relations which results inefficiency. The relationship has deteriorated the workforces' confidence which affect the social welfare of the land because of poor service delivery. It seems there is no clear and understandable strategic approach applicable towards the working relationship. There seems lack of mutual understanding as the relationship between employees and employer, employer and trade unions is concern. In as much as there are guiding principles and procedures towards this union of the concerned parties, what is happening on the ground is defying what ought to be. This has since affected core business of the day as the labour court is flooded with cases which cry unfair practices in labour related issue. Even in government offices, Employment Relations Offices are appointed to deal only with administration of disciplinary procedures. But the most shocking thing is the employer loses these cases with costs to the employees. Now the question is, what is the problem and what can be done to overcome this situation?

\section{AIM OF STUDY}

The aim of the study is to evaluate the Botswana Public Service Sector employee relations model, identify its impotent and present possible recommendations in order to improve and develop an effective long-lasting working relationship between the employer and the employee. 


\section{OBJECTIVES}

The study will be guided by following objectives:

$>$ To evaluate the employee relations model of Botswana Public Service Sector.

$>$ To identify hindrances to work relationships dynamics.

$>$ To recommend suitable practices that could established good employee relations

\section{RESEARCH QUESTION}

The study will answer the following research question

$>$ Is Botswana Public Service Sector employee relations model effective?

$>$ What are the identified gaps that hinder good working relations?

$>$ What can be done to improve the employee relations?

\section{LITERATURE REVIEW}

The Botswana Public Service Sector employee relations framework or model it is a tripartite consultative, it is and always has been the relationship between the employees, the unions and the government who is the employer through the Directorate of Public Service Management (DPSM). The DPSM, being the administrative body regarding civil servant, reports directly to the biggest office in the land, being The Office of the President. The government is the major employer compared to other sectors, therefore it holds quit a large number of the workforce which compelled a need to for a shared interest of employees in regard to making a collective voice concerning their basic rights and demands. Right from the evolution of employment relations in Botswana or rather industrial relations as purported by renowned scholars, trade unionism was inaugurated by the first president in 1971 which however it was not given its full functioning purpose. According to Mokotedi et al (2018) before the year 1997 there was restriction to unionizing it was only after this year that some of International Labour Organisation (ILO) conventions were ratified and adopted. However, there were hindrances to the flow of these conventions even up to this day. The following are some of the major hindrances to a sound employee relation in the Botswana Public Service Sector:

\section{POLITICAL EFFECTS}

Politics are the major effect of the whole spectrum of other factors.

\section{Labour legislation}

All laws in Botswana are made by the parliament which is made up of politicians who affiliates to different political parties. Since independence the Botswana 
Democratic party (BDP) has always being the dominating ruling party in the history of Botswana government. It always had the majority of members in the general assembly which gave it an overarching power when it comes to making laws. All the 5 presidents coming from the same ruling party has always stuck to implementing the manifesto of their party as to how they saw it fit. The issue of labour laws has always been a challenge as the government has influences our relationships through laws, policies and programs. Most of the laws are outdated as they are unfavorable to workers because globalization has brought a lot of dynamics since independence that compels review of some laws. This has created an acrimonious working relationship between the government, the unions and the employees even with the ILO. Trade disputes act, Prisons Act and Trade union and employment organisations Act has some compelling issues as they are unsatisfactory as per the ILO conventions. The issues that need changes as per conventions are said to be hostile and unjust to the employees but favors the government. All these make it impossible for good employee relations since they even limited the jurisdiction of the industrial court which handles trade disputes resulting from unfair work practices, hence creating a backlog of labour cases in a way denying workers justice. Mokotedi et al (2018) therefore, the labour laws in Botswana still have loopholes of abuse of power over workers, oppressive and unjust practices.

\section{Labour relation practices}

\section{Industrial relations}

IR is the terms used to cover working conditions such as rate of pay, annual leave and sick leave according to (safework 2020). (Tichapondwa 2007:4) stated that industrial relations deal with the response of workers and managers to the set policies and functions of the business. One other hand, labour relations involves the relationship that exist between an employer and an employee. The subject deals with the relationship of people in a work environment and take cognizance of their actions, reactions, processes, rules and regulations that surround them and influence their relationships.

In this, there are three distinctive theories of IR which are generally described as the unitary, pluralist and Marxist approaches make quite different assumptions about the nature or organizations, work, society and consequently new conflict and the role of trade unions differently according to (Wikipedia 2020). However, it is important to bear in mind that each approach also encompasses variations: the unitary ranging from authoritarian to paternalistic, the pluralistic including cooperation as well as conflict. The Marxist perspective is sometimes referred to as the conflict model. Each offer a particular perspective of work place relations and will therefore interpret such events as workplace conflict, the role of trade unions and job regulation very differently.

However, the approach for Botswana Public service sector has displayed to be pluralistic, as political leadership is still being a major challenge by having absolute domination, from making of the law to govern the workforce they still making it 
difficult to actually use these law unless they favor the government over the workers. Botswana as a member of ILO is expected to adhere to the conventions that are brought forth by this world labour governing body, but it has been proven that the violates most of these resolution and they take time to ratify some that have been brought forth as far as labour relation practices are concerned. The 2011 public servants mother of strikes in the history of Botswana has expose the government's hostility toward labour relations. We saw the government violating ILO conventions buy add some cadres to the essential service category just so as they can threaten worker to abandon the strike and go back to work or face the consequences of noncompliance. And that was the instruction from the biggest office in the country. This has proven that the government or rather the administration of then was intolerant in recognizing workers demand but putting controlling, restrictive and oppressive measure so as to deny the workers to exercise their rightful right in advancing their demand. Marobela (2014), Mwatcha (2015) According to ILO conventions prisons workers have to be given the right to unionize but they are put under the disciplined forces and are considered as an essential cadre which is in violation of labour relation practices and the obligation of the government as per the conventions.

\section{Trade union}

According to Armstrong (2006:766) trade unions is used to promote and protect the interests of their members. They are there to redress the balance of power between employers and employees. The basis of the employment relationship is the contract of employment. But this is not a contract between equals. Employers are almost always in a stronger position to dictate the terms of the contract than individual employees. There are various registered trade unions representing different industries. Organizations have collective agreements with trade unions or employee organizations, and such agreements are in written form. One of the union's role is to act on behalf of all its members (employees) to represent, consult and negotiate with employers. For instance, on issues pertaining to working conditions, unfair dismissal, training, disciplinary action, and wage negotiations. Employers are encouraged by employment policies to share as much work-related information as possible, to minimize conflicts and to facilitate collective bargaining processes. Employees are encouraged and free to join trade unions to protect and represent their interests at work. To supplement the role of trade unions and to further enhance consultation and communication between the government and its employees, joint ministerial-staff consultative machinery was introduced in 1998 as stated (Kamoche et al 2004:32).

Kamoche et al (2004:32) emphasized that the objectives of the consultative committee are to, amongst others, consider terms and conditions of service, advice on methods to improve general working conditions, and to improve productivity and staff relations but this has not been the case in Botswana. Over the years, there have been conflicts between government and trade unions over issues relating to pay, resulting in strikes. For example, in 2011 the nation saw the largest public service strike over salary increment hence the government ended up dismissing other public 
servants like nurses. However, the events of the 2011 public service strike have ostensibly masked the positive evaluation that Botswana is Africa's economic miracle and a shining example of democracy. As it will be shown by the findings of this study, the current leadership has failed to preserve the exemplary governance and human rights record. The then leadership did not have the economic well-being of the working class at heart. There was an escalation in the militarization and personalization of power in Botswana. As a result, democracy and governance had been seriously undermined (Mwatcha, 2015:16).

It now is evident that trade unions in Botswana are not partners towards labour relations, rather they are treated like subordinates by the employer who in this case is the government. According to Mahapatro (2010) union are there to ensure protection and promote the interest of the workers that have subscribed to their membership against unfair labour practices and discrimination.

Finally, Trade unions in Botswana are drifting from their mandate toward their members. They have now turned into businesses and political affiliates, and this had degraded their responsibility of representing their members. There is bitter rivalry within the leaderships of union even between the unions themselves as now there is conflict of interests. Courts of law are flood with lawsuits of trade union leadership as they are now fighting to acquire riches for themselves at the expense of workers' welfare, some are accused to side with the employer by others which makes it difficult to have one strong voice for the workers as the house is now divided. Therefore, this has given the employer an opportunity to be a sole performer in labour relation matters and do what works better for themselves and leave the masses in unfavorable labour relations climate.

All these leave employees as victims of labour practices at the hand of the employer and deduced substantive power of trade unionism, the Botswana Public service sector has no impressive record as far as employee relations are concerned. This has left one fail to define employee relations as far as it is practiced in Botswana. It is less likened to how Armstrong (2006: 736) defines employee relations, as consist of all those areas of human resource management that involve relationships with employees - directly or through collective agreements where trade unions are recognized. It concerned with generally managing the employment relationship. Employee relations practices include formal processes, procedures and channels of communication. It is important to remember, however, that employee relations are mainly conducted on a day-to-day informal basis by line managers and team leaders; without the framework of employment and employee relations policies but acting mainly on their own initiative (Gennard, \& Graham, 2010:28). ER also covers the abroad subject under the following area the framework of employee relations, the conceptual frame work of industrial relations, ER procedures, trade union recognition collective bargaining, processes for employee involvement and participation working condition and partnerships. In Botswana there are no good relation practices. 


\section{Collective Bargaining}

Armstrong (2006:778) stated that Collective bargaining is a power relationship that takes the form of a measure of power sharing between management and trade unions (although recently the balance of power has shifted markedly in the direction of management). Its aim is to establish by negotiation and discussion agreed rules and decisions on matters of mutual concern to employers and unions (employees) as well as methods of regulating the conditions governing employment. It therefore provides a framework, often in the form of a collective agreement. It is also described as a joint regulating process, dealing with the regulation of management in its relationships with work people as well as the regulation of conditions of employment. It has a political as well as an economic basis both sides are interested in the distribution of power between them as well as the distribution of income. The collective bargaining council in Botswana made up of Directorate of Public Service Management (DPSM) which is the employer, the Trade Unions which represents employees and the Government.

With all that pertain to collective bargaining, the unhealthy relationship between the government being the employer and trade unions has collapsed the bargaining power. We have witnessed the employer defying the Public Service act of 2008 in number of occasions, where the President will be announcing a 3\% salary increment during community (kgotla) meetings whilst the Public Service Bargaining Counsel (PSBC) was still in negotiations and have not yet reached a consensus. The government even went as far as appointing the secretariat of PSBC of their choice without the impute of the trade union as it should be. This shows that the government does not recognize unionization hence making unilateral decisions and having absolute power which is somewhat autocratic. The bargaining power of trade unions has proven to be futile.

\section{Working conditions}

According to (Kamoche and at el 2004:32) Under the Factories Act, employers are expected to provide pleasant and healthy conditions at the workplace. Issues of healthy do not only refers to physical aspect but mentally and emotionally. Therefore, the employer must ensure a conducive working environment in all the aspects. Organizations are expected to provide protective clothing and equipment to protect workers and minimize exposure to hazardous materials and noise. Employers are also encouraged to conduct regular medical examinations for staff members exposed to dangerous materials and working conditions. In addition, organizations are required by legislation to compensate workers injured at the workplace through compensation. Organizations are expected by law to pay terminal benefits to employees dismissed or who die while employed.

Employers are also expected to conform to the national policy on HIV/AIDS, which was introduced in 1998 to minimize the spread and impact of HIV/AIDS and infectious diseases at the workplace. The Ministry of Health, through occupational health units, educates workers through multi-sectoral AIDS committees established 
throughout the country. Employees are made aware of the importance and benefits of HIV/AIDS testing, treatment, and prevention. Some organizations in the private sector, for example Debswana, are complementing the government's efforts in minimizing the impact of HIV/AIDS at the workplace by providing HIV/AIDS support and care. In Botswana public service sector initiatives are their but not in use, when it comes in health and safety issues, employee are not provided by enough protective clothing or equipment needed, only first appointment employee who are taken for medical examination but in General Order no 157 indicated that before the last day in public service they should be a medical examination. This shows negligence's of employee's rights and even SHE's officers are not there in many organisations, the one who should ensure the hazard free environment.

All this goes back to the political effects, as they are the ones driving the administration affairs of the organisation. They are the ones who hold and control the allocation of finance. Employees' health and safety should be a number one priority above all because a healthy worker is a productive worker. The novel Covid19 coronavirus has exposed a lot that is lacking behind when it comes to the government employees' health and safety aspect, especially the primary care giver in the health fraternities. Employees in the health department are exposed to a lot of dangers of infectious diseases as they have been doing their daily duties with inadequate Personal Protective Equipment (PPE). Even rest of the civil servants are facing other health and safety challenging situations for a long time now.

The Botswana Public Servants salary structure are regarded as one of the lowest and below the market value with the current lowest salary A3 scale as per the being paid P24 864 - P28 416 as the annual basic salary which range from P 2072 being the lowest notch - P 2368 being the highest notch per month depending on salary notch within the A3 band. Giving this particular band as an example that can be used in other salary scale it has a range of 10 notches which one accumulate a notch in every financial period which is after every $12^{\text {th }}$ month with terms and condition applied based on the performance and other factors. The accumulative figure between the notches is far too low as P47 the increment between the first and the second notch. This is heart breaking as the cost of living keep on rising at an alarming rate every moment yet workers, pay expensive rent with a decent but small habitable accommodation being P2000 or more monthly and all the basic needs. This situation a has brought a lot of distress and most of employees are faced with a lot of debts as they try to meet their basic need, and this has since affected the working relationship, as most of them are experiencing Illnesses such as hypertension, depression and related diseases.

The government however to respond to these outcries and commissioned PEMANDU consultancy in 2017 to review the entire public service salary structure and the conditions of service. The PEMANDU gave a report which had some lucrative recommendations that would put smile and joy to the public servant if only they were implemented. Up to this time the government being the employer have been sent trade unions from pillar to post regarding the implementation of PEMANDU recommendation. The Patriot (2019). During the 2019 general election 
most public servant expressed their disappointment on the employer and the opposition parties have long highlighted that the minimum living wage have to be at least P 3000 as they felt workers are being taken for granted and exploited. As if it was not enough in the eve of first group payday most employees learned through social media journalism platform that they will not their salary increment that was agreed and signed by the unions and the employer during 2019/2020 salary negotiation. The government decided to defer the increment on the eleventh hour without proper consultation with their representatives. These are bad practices as far as employee relations is concerned. Though the action was done for a good course to fight the covid19 pandemic, consultative management is one of the core elements of a relationship.

\section{CULTURAL EFFECTS}

The public service sector is an organisation, is a social entity, which within it are interrelation of human resource with structures, processes, policies and other resources which are in collaboration towards achieving the mandate of the government, which is providing adequate services to the public. However, all these birthed a culture, the way things are done in the public sector. Culture like political effects have a spectrum of factors that influences employment relations.

\section{Structure and processes}

The Public services sector has one of the tall hierarchical structure which influence employment relations. The structure is rigid and very slow in decision making. It affects the processes, effective communication, employee involvement, participation, and efficiency. Another issue is the leadership and management style. Public sector it still experiences a traditional way of management that is reactive, centralized, bureaucratic and have external control, yet globalization bring changes rapidly. The culture in the public sector needs to be changed to accommodate new trends and concepts that will make a turnaround in the labour climate, managerial practices, and the whole employment relationship. This tall structure affects the progression of workers. Some workers will be in the same band for 10 years which bring frustration and demotivation.

\section{Motivation}

Motivation is the essence of productive, loyal, and high performing workforce. It drives to accomplishment and sense of belonging, an intrinsic fulfillment. The employee relation in the public service sector lack the essence of motivation on the worker because most employees are still struggling to attain even their basic needs. However, human resources management has brought more concepts that are to be used to make thing easier and create a desirable organisational climate. Its concepts or strategies put and recognizes employees as the most valuable assets of the organisations. It seeks to create working environment with harmonious relations, minimized and constructive conflicts, stable social relationship. All these will be 
feasible if jointly employer and employee work together to establishing a fair and just conducts relations. The old way of doing things hinders progress, innovation and growth and it becomes monotonous and demoralizes hence affecting efficiency and it builds up into a culture that is resistant to change.

Price (2007) shares a case study based on the Eulogy of George Cadbury (1839-1922) of a chocolate manufacturing company, who believed that the success of a business lay on cooperation rather than on friction. Cadbury decided to design a way to bring both the company and the man on a good. Since he realised that because of the way people management was done during his time, most worker we demotivated, devastated and there was a huge turnover due to unpleasant working conditions. With the little number of workers, he had left he decided to do something out of the ordinary so that he can keep them and keep the family company running. He started to be closer to his workers in order to win their loyalty and commitment, and that was considered inappropriate that time for a master to have a personal relation with worker as they we considered as working machines. Cadbury used incentive rather that a harsh practice to promote improvement and punctuality, the employees started to be address their first names and he spared some afternoon hours just so he can play cricket with employees. All these benefited the company it grew and kept employing a large number of employees as years goes buy. This was a work of motivation, recognition of workers as partners and acknowledgement.

\section{DISCUSSIONS}

Botswana as a member of the International Labor Organization it had to rectify several conventions which it did well, however these are not implemented. E.g. the right to association is quite restricted as in Botswana the right to strike is nearly impossible. This study established that there is a historical conflict between Botswana's trade unions and the government as it seems the government has more power than trade union which means that public service sector's interests are in the mercy of the government, for example, in 2011 the nation saw the largest public service strike over salary increment whereby some employees contracts such as nurses were terminated.

\section{FINDINGS}

The findings of the study show that the statues are just there and not implemented or other organizations implemented it in different way, looking at schemes of service that recognizes administrators' qualification, responsibility, experiences and accountability says that if he/ she are holding Certificate in Human Resource Management should promoted to $\mathrm{C} 4 / \mathrm{C} 2$, e.g. in the ministry of Investment Trade and Industry CHRM are nothing like that no more progress.

$>$ The study shows that the practices of models in Botswana from development to implementation and monitoring is the domain of the public service.

$>$ Trade unions are more of business entities than workers' representative focused. There is a conflict of interest with trade union leaders. They have abandoned 
their core duty of representing their member on better salaries, conditions of service. But rather they are busy with making profit out of member subscription that does not even benefit members in any way except to put them in more debts through loan and cellphone and airtime contracts.

The labour laws of Botswana are outdated therefore causing contradictions in labour matter not only for the public servants but even for employees in other sectors. They diminish the rights and welfare of employees.

\section{RECCOMENDATIONS}

$>$ The Botswana constitution together with laws that governs the public service sector need to be reviewed and changed as per the conventions of ILO in order in order break a rigid wall between the employer and the employees working relationships.

$>$ The employer must be taking full responsibility and be committed toward creating a harmonious working relation with the employees by benchmarking and trying out new concepts and trends of human resource management policies and strategies that are brought by globalization.

Public Service Bargaining Counsel (PSBC) must be afforded the opportunity to function independently without the interference and influences of the Office of the President on issues of collective Bargaining. There must be equal power sharing between the employer and the unions

$>$ Trade unions must find a way to collaborate and make one body and come up with labour relations framework that will able to accommodate all sort of employment sector, so that they can speak with one collective voice and avoid some unions unrecognized because they don't meet the required threshold to collectively bargain.

$>$ A restriction to some of employees' rights such as The right of association must be lifted so that employees exercise their right to reduce or neutralize the possible oppressing and unjust power of the employer

\section{CONCLUSION}

Employee relations are vital in organizations as it provides effective and consistent procedures for rule making, consistency in dealing with employees relations issues, fairness, process that can affect and improve employer behavior or ways to resolve disputes or differences between employer and employees. With good employee relations positive and value added outcomes such as improves morale and commitment, increased productivity, fewer complaint or grievances in the workplace will be observed. In today's time there is need for a good clear and firm employee relations model that mitigate the relationship between employer and employees, unions in order to scope, to raise and resolve grievances and conflicts hence ensuring good working relation between employee employer. This will ensure the pay work 
bargain which is basically what the employee relation is all about. There also seems to be a large amount of room for growth for HRM activities as the economy develops further. However, it must be emphasized that the current state of affairs to the uncertain political or economic environment is not conducive to development. Therefore, political stability, along with rules of good governance, should be achieved and sustained if Botswana wants to recognize its public service sectors needs to enhance their productivity in order to maximize the full potential of the economy as Routledge (2001:118) noted

\section{REFERENCES:}

- Armstrong, M. (2009:878). Armstrong's Handbook of Human Resource Management Practice (11th ed.) London: Kogan Page.

- Armstrong, M. (2006). Armstrong's Handbook of Human Resource Management Practice (10th ed.) London: Kogan Page.

- Botswana NDP9, Chapter19, Public Sector Management

- Elischer H. (2008). Trade Unions in Botswana, Country Report. Gaborone:

- Friedrich Ebert Foundation.

- Gennard, J. \& Graham. J., (2010:28). Managing employment relations. London.

- Kamoche, K, Debrah .Y, Horwitz.F \& Muuka .N.G (2004:31-32) Managing Human Resources in Africa, 11 New Fetter Lane, London EC4P 4EE

- Mahapatro, B.B., (2010) Human Resource Management, New age International

- Marobela, M.N., (2014) Industrial relations in Botswana workplace conflicts: Behind diamond sparkle, Emerald Emerging Markets case studies, Vol.14 Iss 2 pp 1-16

- Mokotedi, K., Mothusi, B., Thalefang, J.B., Maruping, M.S., (2018) Trade Union Country Report, Friedrich Ebert Stiftung, Gaborone

- Mwatcha M .P. (2015:16-23) Botswana's Labour Relations System: lessons from 2011, University of Witwatersrand, Johannesburg, South Africa

- Price, A., (2007) Human Resource Management in a business context, $3^{\text {rd }}$ edition, Thomson Learning, London.

- Routledge (2001:118) Human Resource Management in Developing Countries, $11 \mathrm{New}$ Fetter Lane, London EC4P 4EE

- The Patriot on Sunday (2019) Masisi, civil servants clash over PEMANDU recommendations. Available at www.thepatriot.co.bw, (Accessed: 02/06/2020)

- Tichapondwa S. M. (2007:4) Botswana College of distance open learning

- www.safeworksagov.au/./case

- www.en.wikipedia.org/industrialrelations 